\title{
A Neuro Linguistic Programming's modelling process for the development of and guidance to congregations: An adaptive ministry
}

\begin{tabular}{|c|c|}
\hline \multicolumn{2}{|c|}{$\begin{array}{l}\text { Authors: } \\
\text { Johan Bester }{ }^{1} \text { (]) } \\
\text { Johann A. Meylahn } 1 \text { (1) }\end{array}$} \\
\hline \multicolumn{2}{|c|}{$\begin{array}{l}\text { Affiliations: } \\
\text { 'Department of Practical } \\
\text { Theology, Faculty of Theology } \\
\text { and Religion, University of } \\
\text { Pretoria, Pretoria, } \\
\text { South Africa }\end{array}$} \\
\hline \multicolumn{2}{|c|}{$\begin{array}{l}\text { Research Project Registration: } \\
\text { Project Leader: J.A. Meylahn } \\
\text { Project Number: } 02187133\end{array}$} \\
\hline \multicolumn{2}{|c|}{$\begin{array}{l}\text { Description: } \\
\text { Dr Bester is participating in } \\
\text { the research project, 'Towards } \\
\text { a practical postfoundational } \\
\text { theology as public theology in } \\
\text { response to the challenges of } \\
\text { lived religion in contemporary } \\
\text { Southern Africa', directed by } \\
\text { Prof. Dr Johann Meylahn, } \\
\text { Department of Practical } \\
\text { Theolgy, Faculty of Theology } \\
\text { and Religion, University of } \\
\text { Pretoria. }\end{array}$} \\
\hline \multicolumn{2}{|c|}{$\begin{array}{l}\text { Corresponding author: } \\
\text { Johan Bester, } \\
\text { jbester@mweb.co.za }\end{array}$} \\
\hline \multicolumn{2}{|c|}{$\begin{array}{l}\text { Dates: } \\
\text { Received: } 18 \text { Jan. } 2019 \\
\text { Accepted: } 19 \text { Feb. } 2019 \\
\text { Published: } 06 \text { Aug. } 2019\end{array}$} \\
\hline \multicolumn{2}{|c|}{$\begin{array}{l}\text { How to cite this article: } \\
\text { Bester, J. \& Meylahn, J.A., } \\
\text { 2019, 'A Neuro Linguistic } \\
\text { Programming's modelling } \\
\text { process for the development } \\
\text { of and guidance to } \\
\text { congregations: An adaptive } \\
\text { ministry', HTS Teologiese } \\
\text { Studies/Theological Studies } \\
\text { 75(4), a5389. https://doi.org/ } \\
\text { 10.4102/hts.v75i4.5389 }\end{array}$} \\
\hline \multicolumn{2}{|l|}{ Read online: } \\
\hline 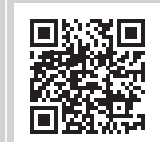 & $\begin{array}{l}\text { Scan this QR } \\
\text { code with your } \\
\text { smart phone or } \\
\text { mobile device } \\
\text { to read online. }\end{array}$ \\
\hline
\end{tabular}

Several congregations in the workspace of the Netherdutch Reformed Church of Africa are losing viability and sustainability. This can be attributed to various factors, the most prominent being isolation. Isolation is defined here as the inability of some congregations to move away from maintenance and an inward focus towards making necessary adjustments on the way to a dimension of missional focus. While commitment and enthusiasm are present in the work of all congregations, some find it difficult to adapt their established ideas and in some cases obsolete customs and traditions. Other congregations have made the necessary adjustments by defining themselves as missional. In congregations where constructive change occurs, the focus moves to undertake congregational ministries. The congregation not only gains insight into their own situation but also becomes aware of God's calling for that specific congregation within a specific context. The focus shifts from their own situation and needs to the needs and challenges of the context surrounding the specific congregation. A consequence of this change in focus is that the whole ministry of the congregation adjusts accordingly. These congregations discover their own unique spirituality and begin to ask: For whom do we exist? The article is based on a PhD thesis, where Osmer's four questions of practical theology were brought into the conversation with the modelling process of neuro-linguistic programming, in an attempt to sojourn with congregations towards a contextual missional focus. This research was undertaken to expand Osmer's four questions of practical theology by using the modelling process of neuro-linguistic programming so that congregations may succeed in making the necessary adjustments.

Keywords: Neuro-linguistic programming; Modelling; Congregational development; Congregational guidance; Osmer.

\section{Introduction}

The world and the church live in changing and challenging times. More and more congregations of different denominations perceive themselves as trapped or stranded. Some congregations are unable to adapt to their context during the deterioration phase. Others take into account alternative options, despite their deterioration, and manage to adapt to their changing context. The purpose of this research was to determine why certain congregations have the capacity not only to remain sustainable but also to accomplish growth on different levels.

Pat Keifert (2017:264) states that the gospel does not primarily consist of information about Jesus. The gospel is Jesus Christ. Therefore, the church and its members must participate in God's mission in the world, Participatio Christi (Frost \& Hirsch 2009:29). This is the foundation of the missional movement of which the church forms a part. It is more than just the evangelising of the world.

The practical-theological context was examined in a PhD thesis (Bester 2018). The result of that research was the realisation that the answer is complex and multifaceted. The research found that Osmer's approach to practical theology (2006:328-330) with the four tasks within the hermeneutic circle can help pastors and other facilitators of congregational development to determine what is happening in the congregation. The first step is to try and understand what is currently happening in the congregation, this is the descriptive-empirical task. The interpretive task is the second step and processes the collected information and determines why the events took place. It is at this

Note: HTS 75th Anniversary Maake Masango Dedication.

This article represents reworked aspects from the PhD dissertation of Johan Bester, prepared under the supervision of Prof. Dr Johann Meylahn, Department of Practical Theology, Faculty of Theology and Religion, University of Pretoria.

Copyright: (C 2019. The Authors. Licensee: AOSIS. This work is licensed under the Creative Commons Attribution License. 
point that an interdisciplinary conversation with other sciences should take place, not only to research other possibilities but also make them part of the conversation. The third step, the normative task, helps to determine what should happen in that congregation within that specific context. The conversation between the normative and the interpretive task will then lead the congregation towards a transformed praxis, which is the fourth step in Osmer's approach.

With the help of neuro-linguistic programming (NLP) theories and techniques, pastors are enabled not only to determine what is presently happening with the particular congregation but they should also learn from other congregations what procedures and actions may occur (what can possibly happen). The modelling process is a handy and useful tool that enables congregations to journey towards a more missional and sustainable model. The work of the Holy Spirit must always be taken into account, for it is God himself who maintains his church on earth and who lets the church thrive. NLP techniques can empower leaders and facilitators to help them sojourn with congregations in understanding themselves as well as the context of the congregation and seek in conversation with Scripture and the founding documents new ways to respond to the current challenges and, thus, become missional congregations.

According to Smit (2001:5), congregations should act with religious conviction to determine God's calling and sending of their particular congregation within its specific context. With these development and guiding processes, congregations not only discover their own identity but also their unique spirituality, their unique calling within their context. The spirituality question is always: For whom does the congregation live or exist? The role of the leaders in the congregation can be understood in the words of Smit: 'The shift that goes with this aspect is from religious official to spiritual guide' (Smit 2001:7).

Congregations that focus on God and the missio Dei will expect primarily of the congregational leadership to constantly remind the members of the presence of God in the lives of his people on earth and seek God's presence within the context. Ephesians 1:19 assures us that the same power by which God raised Christ from the dead is at work in us. Therefore, God's presence is a reality in the life of his congregation and not the result of spiritual development. It is the task of every pastor to remind his or her members about this. A Coram Deo existence demands that the faithful be guided to live with an acute awareness of the reality of God's presence in the context.

Intentional interim ministry can be invaluable here as it sojourns with congregations to rediscover God's calling and presence in their specific context. The premise of intentional interim ministry is precisely that a vacant workspace in a congregation can be the best time for change. The interim pastor must take this into account when he or she begins to work in a congregation. This is not the same as strategic planning.
Osmer's (2006:328-330) four-task methodology was followed in this research in which practical theology functions within a hermeneutic circle or spiral:

- Descriptive/empirical task: What is happening? Information is collected to understand specific social events.

- Interpretive task: Why is it happening? There is dialogue with social sciences to explain why certain events are occurring.

- Normative task: What should happen? Normative questions are asked.

- Pragmatic task: How are we going to respond to this and how will we apply it? This has to do with action plans and understanding certain reactions within each situation.

This model can now be brought into creative conversation with the research question.

\section{Why do some congregations perceive themselves as trapped or stranded?}

Many pastors and congregational facilitators are convinced that secular strategic processes, mainly developed within the field of economic and management sciences, can regenerate the congregation. It is surprising that some church councils believe that the church council can determine the strategic course of the congregation, while Jesus teaches us unequivocally that he will build the congregation himself. Certain secular resources are indeed useful, but definitely not to determine the future of the congregation. It is God who has a promised and preferred future for his church and who invites the members of the congregation to go on this journey with him. The congregation is always in the process of (re) discovering its calling and spirituality under the guidance of the Holy Spirit.

The following are possible reasons for the perception of being trapped or stranded:

- We have forgotten how to live with an awareness of God's presence in the congregation and context.

- Missio Dei theology is sometimes, if not always, absent (Marais 2017:75).

- The training of pastors has not taken the changes of the context into consideration and; therefore, pastors do not feel equipped to minister in such changed contexts.

- The effect of church building programmes. The premise of these programmes is always from the church's perspective. Statistics that were considered to evaluate were church attendance, budgets, etc. The point of departure was never the fact that God called us to join his missio Dei.

- There is a lack of integration of the missio Dei in our leadership theory (Van de Beek 2013:63-81). There is too much emphasis on human ability in the renewal of congregations. Congregational leaders have forgotten that God, as the source, gives the energy and the wisdom, and that the Triune God actively creates the religious 
community and that he calls us to become part thereof. Missio Dei means that leadership begins by receiving and not with own creation and functionality.

- Since church councils predominantly come from the secular world, and due to the fact that congregations must and can learn much from them, we must remember that the cross and the Holy Spirit are absent from nearly all their management and leadership models.

- Congregations define themselves in terms of themselves, instead of in terms of the kingdom of God.

- Congregations call leaders and allocate leaders to minister to the congregation. In other words, they define themselves in terms of their understanding of their own needs, while the Bible clearly states that the church must be defined in terms of the coming of the kingdom of God. Most congregations, therefore, lean towards a position of power - even missionary theory is then translated in terms of the attraction model: How do we assemble a bigger audience?

- Our theological understanding of our office as king, priest and prophet excludes the apostolic function. The Christian movement was established after the death, resurrection and ascension of Jesus Christ by the power of the Holy Spirit, and the expansion of this movement was entrusted to the apostles, disciples and other followers of Jesus to whom Jesus gave the command to proclaim this message to the whole world (Keifert 2007:21). The task of the church is to form a new religious community, and an understanding of our apostolic office will help us to redefine our identity and calling.

\section{What should happen in congregations?}

The calling of the congregation embodies the theology of missio Dei. Missio Dei means the following:

- The church is called and sent by the Triune God to spread the gospel and to form new religious communities. Missio Dei is the mission of God: The Father who sent the Son, the Son and the Father who sent the Spirit, and the Son who sends the congregation with the Spirit who guides, encourages, comforts and empowers. God's nature is love and light, but God's character is missionary. It is, therefore, not the church that does the missionary part, but the church is called by God to join God's mission (Keifert 2017:265).

- It is God's mission that wishes to include us. God's mission continues and the church is called to join God in his work within the specific context of the congregation. The church does not have a mission separate from her identity, because to be church, is to be called and sent; to be church, is to be called, gathered, centred and sent as part of God's mission. And God invites us to join him where he works (Keifert 2007:22).

- Therefore, the church does not do things merely because it chooses to do so or because the church law demands it. We do what we do because of our love for God. In accordance with 2 Corinthians 5:14: 'For Christ's love compels us, because we are convinced that Christ died for all'. Keifert (2017) aptly states:

Missio Dei was an expression of the doctrine of the trinity - namely the expression of the divine sending forth of self, the sending of the Son and Holy Spirit to the world. (p. 268)

- God invites us to be cocreators with him. God is already working, we can simply join him. This means that we do not go out and invite God to come with us. God already went ahead of us (Lk 10) and invites us to join him. We often make plans, even in the Name of Christ, and then we ask God to bless our plans and to come with us. No, God went before us. When we reach the people God sent us to, we will discover that God is already at work there.

\section{A definition of a missional congregation}

Reggie McNeal (2009:23) regards a missional congregation as follows: 'The missional church believes it is God who is on a mission and that we are to join him in it'. Newbigin (1989) describes it as follows:

It seems to me to be of great importance to insist that mission is not first of all an action of ours. It is an action of God. This may lead to an own definition: A congregation that is the difference and that makes a difference, not only in the lives of her members, but also in the community of which she forms part. (p. 134)

\section{How will we apply this? With an adapting ministry}

Intentional interim ministry is, therefore, not merely a technical change that has to occur in the congregation. Not only the congregation's maintenance has to be carried out differently but an adapting change has to occur. This change can be initiated when the congregation (re)discovers her identity in God's mission.

This can possibly be a design flaw in the method of interim ministry. According to Dilts's neurological levels of change (Knight 1999:88) identity merely asks: who is the congregation? However, the spiritual question remains unasked and unanswered, namely: For whom does the congregation exist/live? The answer to this spiritual question can help to determine the congregation's future. It can be the difference between mere maintenance and transformation. For example: The congregation's identity can be understood as being a congregation of Christ. But they can still live for themselves, by asking: How can we get more people into the church? By contrast, a congregation of Christ that lives for him alone asks: how can we motivate the whole body of Christ to be involved in God's mission in our part of the world? The church as being sent rather than as having a mission, did not so much focus on getting people into the church, but on being church in the everyday life among and with friends, neighbours, colleagues and strangers (Keifert 2007:22). Leslie Newbigin (1989) also confirms this: 
The church is not meant to call men and women out of the world into a safe religious enclave but to call them out in order to send them back as agents of God's kingship. (p. 136)

Indeed, it is and remains Christ's great command in Matthew 28:16-20. Such an attitude reflects a kingdom perspective. The church remains in the service of the kingdom of God.

Here the neurological levels of change can be useful to develop and guide congregations:

Spirituality has to do with man's internal journey and relationship with a higher Being, in this case with the Lord God. For an organisation such as the church this means the calling of the congregation and the interaction of the congregation with the community and other organisations (O'Connor 2001:29). The questions that are asked are the following: For whom do I do what I do? For whom do I live? (Harris 1998:43).

Identity has to do with how someone thinks about himself or herself; how you see yourself and talk about yourself. The values and beliefs that define you and your purpose in life. A person expresses himself or herself through behaviour, skills, values and beliefs. Yet we are more than any of these levels. It describes the culture of an organisation (O'Connor 2001:28). The questions asked are: Who are you? Who am I in Christ?

Values and beliefs are part of the building material that makes each person what he or she really is. Changing values and beliefs may lead to new objectives and meaning (Tosey \& Matison 2005:152) - what you believe about yourself and that which is important to you. These values and beliefs influence personal capabilities, which in turn determine your behaviour, while behaviour influences the environment. In the church environment these are the principles of religious actions and existing values. The question asked is: Why is it important to you?

Capabilities are not concerned with the person's qualifications and experience, but with the skills we apply to reach results and goals. On an organisational level, these are the processes and procedures that are put in place. The questions asked are: What are your capabilities? Which do you need?

Behaviour includes what you think, say and do, and also 'how' things are done. Behaviour is the most difficult level to change since behaviour is always perceived from the outside (O'Connor 2001:28). The question asked is: what are your behaviours?

The environment is the immediate environment where you operate. It is more than the location. It also includes the time and the people that influence your decisions and behaviour. It determines the parameters of all that is included. The questions asked are: When? Where? (O'Connor 2001:28-29).

In the research (Bester 2018), the story of two congregations was researched. Both congregations were going through a process of interim ministry. The congregations, A and B, which were defined in a descriptive-empirical manner, not only (re)discovered their own identity with the application (where the congregation takes part in discussions) of the neurological levels of change but also their unique calling and spirituality. The calling in turn signifies God's preference and promised future for the specific congregation in that particular context. That is why it is preferable to guide the congregation to the (re)discovery of her calling and spirituality, instead of only her identity.

See O'Connor's (2001:29) schematic representation of the neurological levels of change (Figure 1).

These logical levels do not form a hierarchy with spirituality at the top and the environment at the bottom. The levels are interconnected and influence each other. A change on one level will necessarily affect the other levels ( $\mathrm{O}^{\prime}$ Connor 2001:28-29). Dilts, quoted by Tosey and Matison (2005), states the following:

This denotes that change at a higher level (e.g. identity) has more far-reaching consequences for the person in that this is likely to affect an increasingly wide range of beliefs, capabilities and behaviours. (p. 149)

When a problem develops on a specific level, the other levels must be tested to ensure that those levels function correctly. Therefore, each of these levels involves a person's neurology (Harris 1998:43). These neurological levels of change form part of the modelling process. The answers to the questions on each level help the NLP user to establish a profile and data bank of each one that is modelled. This information can then be applied when new capabilities and skills have to be learned by other persons who do not have the specific capabilities and skills. Or in the words of Dilts:

The concept of logical levels of learning and change was initially formulated as a mechanism in the behavioural sciences by Gregory Bateson, based on the work of Bertrand Russell in logic and mathematics. The term logical levels, as it is used in NLP, was adapted from Bateson's work by Robert Dilts in the mid-1980s and refers to a hierarchy of levels or processes within an individual or group. The function of each level is to synthesise, organise and direct the interactions on the level below it. Changing something on an upper level

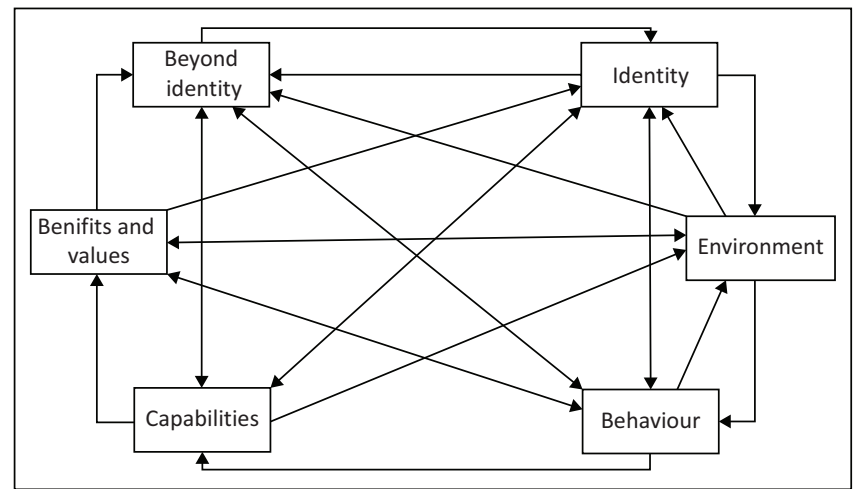

FIGURE 1: Neurological levels of change. 
would necessarily 'radiate' downward, precipitating change on the lower level. Changing something on a lower level could, but would not necessarily, affect the upper levels (Dilts et al. 1991:688).

According to O'Connor (2001:30), one can determine on which level a person thinks by merely listening to the words used. O'Connor uses the example of: I can't do that here:

- If the $I$ is emphasised, it is a statement of identity. I can't do that here.

- If the can't is emphasised, it is a statement of belief: I can't do that here.

- If the do is emphasised, it is a statement of capability: I can't do that here.

- If the that is emphasised, it is a statement of behaviour: I can't do that here.

- If the here is emphasised, it is a statement of environment: I can't do that here.

The idea with the neurological levels of change is to help with the thinking process. It makes it possible to distinguish between the action and the person, since many people judge themselves by what they do. A child is often regarded as naughty (identity) if he or she does something wrong (behaviour). The neurological levels of change are, therefore, not meant as a mechanistic technique. If you know on which level you perceive yourself as trapped or stranded, you can more readily find a solution (O'Connor 2001:30).

That is why it is essential to acquire new capabilities during changing circumstances. The purpose of these capabilities is not only to reaffirm or determine the own identity of the congregation but especially to make the necessary adjustments regarding the calling and spirituality of the congregation. This will inevitably mean that other congregations in similar situations can be modelled for help and advice.

The fact that people know and/or obtain insight is not a required condition for behavioural or attitude change. It is not enough even for the Christian believer just to hear that he or she should live their Christianity every day (Kruger \& Bester 2002).

With the NLP approach, one could answer that information has an effect when an outcome meets certain criteria:

- Where information is linked to a capability, such as how to carry out a specific action.

- You know or understand what is required.

- To know more, for the sake of new knowledge.

- In the context of decision-making, where 'understand' (having an understanding of the cause with a view to preventive thinking) is regarded as a prerequisite for effective decision-making (Alder \& Heather 1999:37-39).

According to the NLP approach information, which should lead to attitude renewal or change, should be converted to a reference experience. One lives from this place that is called experience. Behaviour is formed as a blueprint from experience before the behaviour is carried out. Within the experience, the final test for the recognition or approval of content is in a person's thoughts. This test is verbally expressed as follows:

- It feels good.

- It seems acceptable to me.

- It sounds right.

Or negative content, if the test is not successful (Kruger \& Bester 2002).

From experience, we know that nothing happens when people listen and listen attentively. Please test your own experience of a similar incident. It is as if the information remains on the level of words: The hearing action is not followed by any specific pictures, sounds or feeling processes that are necessary to internalise the information; in other words, it is not converted into a personalised reference experience.

The study that NLP made of the internal processes of top achievers (in business, leadership and sport) indicated that the more distinctions are made in experience, the more effective or competent the person becomes in reaching his or her outcomes. Christianity as a philosophy of life, in a world that is inherently hostile to the practice of Christianity, requires all the appropriate distinctions in experience to remain faithful to the calling of Christ. The calling of Christians requires the difficult but constant distinction of: What is the Christian thing to do now?

Smit (2001:11) is probably right with his comment: 'The practice of ministry does not call for quick answers, but for careful reflection and wise discernment'. Browning (1991:1) in turn urges: '.. for the recognition of the practical wisdom present in communities of faith and proposes a new route for the process of theologising: from practice to theory and back again'.

The research showed that there is not one process that would suit all congregations equally well. The circumstances of each congregation will have to be taken into account properly before a theoretical approach for the specific congregation can be chosen. This can happen only if the work is done consistently and with religious discernment.

Reggie McNeal (2009:50) states that we are moving away from the Attendance, Buildings and Cash (ABC) measuring method to a Missional, Relational and Incarnating (MRI) measuring. According to him, congregations should obtain a different scorecard for the measuring. That is why a number of questionnaires were developed recently to determine more rapidly what lives in the hearts of the congregation. When these questionnaires have been processed, it can help to plan the ministry in the specific congregation. 


\section{Questionnaire 1}

1. Which events in the past affected the congregation positively?

2. Which events are currently affecting the congregation?

3. Do you believe that the leadership can lead the congregation to a new future?

4. What change in the community affects the congregation?

5. What new things do you think is God doing in the congregation?

6. What is your hope for the future of the congregation?

The sustainability index (Bester 2017) was developed in cooperation with an industrial engineer to assist congregations in acquiring insight into and understanding of their context - precisely because congregations do not wish to or cannot manage to understand the actual seriousness of the situation. The sustainability index helps to bring congregations to the point where they are confronted with the reality of their situation. In the sustainability index the emphasis is not on finances but on the missional nature of the congregation. The missional questions were adapted from McNeal's (2009) recommended alteration of the scorecards of congregations. Previous research (Bester 2015) showed that congregations that make missional adjustments are more likely to survive in the long term than congregations that continue to focus on maintenance. For the complete questionnaire, refer to the $\mathrm{PhD}$ thesis of Bester (2018).

The percentage of the weight for each question is indicated in Figure 2.

\section{Dwelling in the world}

This method is used with the permission of the Church Innovation Institute. With the information gathered in this way, we can determine where God is already active in the congregation. Every member indicates his or her own involvement for each of the seven items and encircles the three where they are most involved. This can help the congregation to (re)discover her calling.

\section{Spirituality wheel of Corinne Ware}

The spirituality wheel helps the congregation to determine their spirituality type by means of a questionnaire. For the sake of completeness, a short summary of each spirituality type is given.

Corinne Ware mentions in her book Discover Your Spiritual Type (1995) that there are four types of spirituality, which are presented below.

\section{The head spirituality}

\section{Approach}

Focuses strongly on the rational, logic and reasoning.
God's voice is most clear when:

- the mind is addressed

- a new understanding of God is reached

- faith can be researched and explained.

\section{Conversation with God}

People in this spirituality focus in prayer on:

- logical structure

- guidance from Scripture.

\section{Outcomes}

- Bible study

- confessions of faith

- doctrines and dogma.

\section{The heart spirituality}

\section{Approach}

Focuses on an emotional relationship with God through experience.

God's voice is most clear through:

- worship

- music

- spontaneous prayer.

\section{Conversation with God}

The prayers of persons with this spirituality are intense and personal.

\section{Outcomes}

- prayer groups

- testimony

- praise.

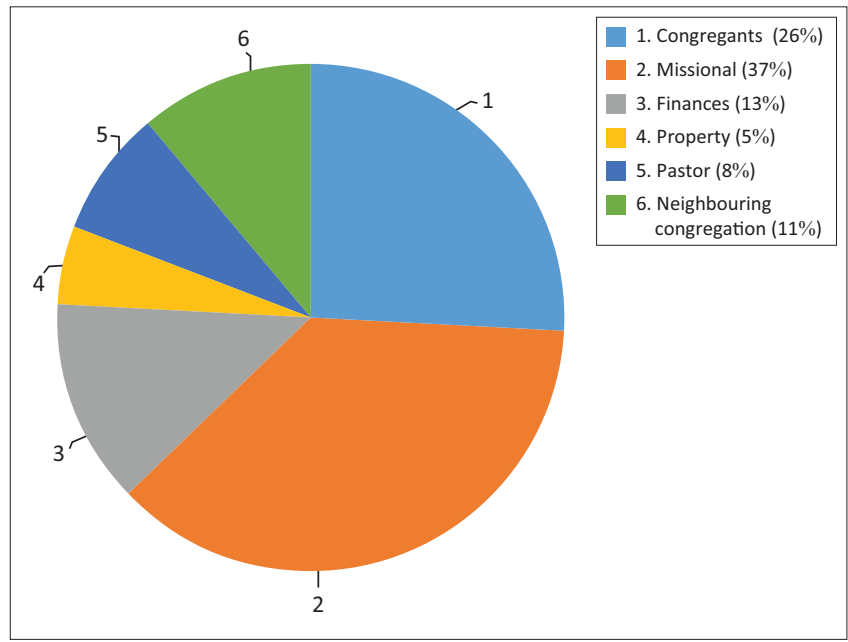

Neighbouring congregation $-11 \%$; Pastor $-8 \%$; Property $-5 \%$; Finances $-13 \%$; Missional $-37 \%$; Congregants $-26 \%$.

The questions of the sustainability index are comprised as follows: Congregant questions $1+2$; Missional questions 3-6; Finances questions 7-9; Property questions $10+12$; Pastor question 11; Neighbouring congregations question 13; Environment question 14.

The total score of the index is 37 and is composed as follows: 0-9 Not at all sustainable; 10-14 Not sustainable; $15-19$ Almost sustainable; 20-29 Possibly sustainable; 30 + Sustainable.

FIGURE 2: The percentage of the weighting. 


\section{The mystic (inner) spirituality \\ Approach}

- Focuses on the mystery and greatness of God, which can only be experienced in your innermost being.

- God is too great to be understood, and that calls on us to be humble.

- God's voice is most clear when we are silent.

\section{Conversation with God}

- The prayers of persons with this spirituality are quiet, with few words.

\section{Outcomes}

- Meditations.

\section{The hand spirituality}

\section{Approach}

- Focuses on obedience to God's command.

- God's voice is most clear when his work is being done.

\section{Conversation with God}

The prayers of persons with this spirituality are synonymous with being engaged in God's work.

\section{Outcomes}

- charity projects

- care wards

- service to others.

Every person will probably experience something of God in all four quadrants but will hear God's voice best and answer to it in his or her preferred spirituality type. The church in its work cannot limit itself to one quadrant, especially because no single spirituality type is better than another. If that should happen, it would result in some people never hearing God's voice loud and clear in the church and never really becoming ready for service.

\section{Conclusion}

Congregations that are guided missionally not only discover their own identity and spirituality but also find that a new calling takes form. The congregations realise anew that they belong to the Lord Jesus Christ and that he maintains his church on earth. Therefore, not everything is about the own congregation any more, but about God's kingdom. When there is an understanding of and a vision for the kingdom, congregations no longer live and exist for themselves, but for God and his kingdom. Consequently, the most important focus is no longer to maintain structures, but to serve in the kingdom. This way the congregation's new identity and new spirituality lead to a new calling. The congregation redefines its success in terms of faithfulness to God's calling.

\section{Acknowledgement Competing interest}

The authors have declared that no competing interests exist.

\section{Author contributions}

Both authors equally contributed to the writing and research of this article.

\section{Funding}

This research received no specific grant from any funding agency in the public, commercial, or not-for-profit sectors.

\section{Data availability statement}

Data sharing is not applicable to this article as no new data were created or analysed in this study.

\section{Disclaimer}

The views and opinions expressed in this article are those of the authors and do not necessarily reflect the official policy or position of any affiliated agency of the authors.

\section{Ethical consideration}

This article followed all ethical standards for carrying out research without direct contact with human or animal subjects.

\section{References}

Alder, H. \& Heather, B., 1999, NLP in 21 days; a complete introduction and training programme, Judy Piatkus Publishers Ltd, London.

Bester, J.P., 2015, 'Die rol van Spiritualiteit in die modellering van uitnemendheid in leierskapenbesluitnemingsprosesse: 'n gemeenteontwikkelingsperspektief', Dissertation MTh, University of Pretoria.

Bester, J.P., 2017, 'Brugbediening ' $n$ aanpassendebediening', Unpublished paper at the Network for Interim Ministry in Southern Africa conference, September 2017.

Bester, J.P., 2018, "n NLP modellerings proses vir gemeente ontwikkeling en begeleiding', PhD thesis, University of Pretoria.

Browning, D.S., 1991, A fundamental practical theology: Descriptive and strategic proposals, Fortress Press, Minneapolis, MN.

Dilts, R.B., Epstein, T., Dilts, R.W. et al., 1991. Tools for dreamers: Strategies for creativity and the structure of innovation, Meta Publications, Cupertino, CA.

Frost, M. \& Hirsch, A., 2009, ReJesus: A wild Messiah for a Missional Church, Hendrickson Publishers, Inc., Peabody, MA.

Harris, C., 1998, The elements of NLP, Element Books Limited, Dorset.

Keifert, P., 2007, Ons is nouhier, Translated in Afrikaans, Bybel-Media, Wellington.

Keifert, P., 2017, Missional theology as Trinitarian theology: A conversation with Pat Keifert in Cultivating missional change, Biblecor, Wellington.

Knight, S., 1999, NLP solutions; how to model what works in business to make it work for you, Nicholas Brealey Publishing Limited, London.

Kruger, A.J. en Bester, J.P., 1998, Inligting as veranderingsagent van menslike gedra (p. 8-9), in Die Konteks van Februarie 1998, Vol 9 (2). Pretoria: SENTIK. (Tydskrif van die Nederduitsch Hervormde Kerk van Afrika - redakteur De Beer, P.)

Marais, F., 2017, The history and challenge of the missional movement in South Africa: Perspectives from an insider in cultivating missional change, Biblecor, Wellington.

McNeal, R., 2009, Missional renaissance. Changing the scorecard for the church, Jossey-Bass, San Francisco, CA.

Newbigin, L., 1989, The gospel in a pluralistic society, Eerdemans, Grand Rapids, MI.

O'Connor, J., 2001, NLP workbook: A practical guide to achieving the results you want, Thorsons, London.

Osmer, R.R., 2006, Toward a transversal model of interdisciplinary thinking in practical theology, in The evolution of rationality, pp. 327-345, Eerdemans, Grand Rapids, MI. 
Smit, A.T., 2001, Meetings that matter: Leadership, spirituality and discernment in congregations, Lux Verbi.BM., Wellington

Tosey, P. \& Matison, J., 2005, 'Mapping transformative learning: The potential of neuro linguistic programming', Journal of Transformative Education 3(2), 140-167. https://doi.org/10.1177/1541344604270233
Van de Beek, A., 2013, Gemeente van Christus, Schetsenvoor de Praktijk, Meinema, Zoetermeer.

Ware, C., 1995, Discover your spiritual type: A guide to individual and congregationa growth, The Alban Institute Inc., Washington, DC. 